\title{
Humboldt Meets Bologna: Developments and Debates in Institutional Writing Support in Germany
}

\section{Felicitas Macgilchrist and Katrin Girgensohn}

\begin{abstract}
This article outlines the coming of age of writing pedagogy in German institutions of higher education and explores the role of the 'Hausarbeit' in contemporary universities. Traditionally, the 6,000-12,000 word Hausarbeit was the mainstay of academic writing in all university courses in the social sciences and humanities in Germany. This assignment was tied into dominant discourse ('Humboldt discourse') in which the main point of higher education was to cultivate future independent scholars. Since 1999, the increasing predominance of 'Bologna discourse' has led to the radical restructuring of higher education across Europe. This discourse emphasizes internationalization, transferable skills and key competencies, i.e. the point of higher education is not primarily to cultivate independent scholars but flexible, creative and enterprising future professionals. With indications that the Hausarbeit could disappear in the Bologna process, we argue not only that it can be saved but also that it has a significant role to play in developing the new competencies. This will only happen, however, if students receive institutional writing support, and if writing curricula in Germany rise to the new challenges.
\end{abstract}

\section{Key words \\ writing centres, discourse, Bologna reforms, writing pedagogy, Hausarbeit}

\section{Résumé}

Cet article décrit la maturation de la pédagogie sur l'écriture dans les études supérieures en Allemagne et explore le rôle du Hausarbeit dans les universités contemporaines. Traditionnellement, le Hausarbeit de 6000 à 12000 mots était une composante centrale de l'écriture académique dans tous les cours d'université en sciences humaines et en lettres en Allemagne. Ce travail était relié à un discours dominant (le discours d'Humboldt) selon lequel le but essentiel des études supérieures était de développer l'indépendance des étudiants. Depuis 1999, la prédominance croissante du discours de Bologne a mené à une restructuration radicale des études supérieures partout en Europe. Ce discours met l'accent sur l'internationalisation, les compétences transposables et les aptitudes clés; en d'autres mots, l'objectif des études supérieures n'est plus de développer des érudits indépendants mais plutôt de futurs professionnels qui sont flexibles, créatifs et entreprenants. Motivés par des indications que le Hausarbeit pourrait disparaître à mesure que le processus de Bologne croît en importance, nous soutenons non seulement qu'on peut le sauver mais aussi qu'il a un rôle significatif à jouer dans le développement de nouvelles compétences. Cependant, l'Hausarbeit ne sera préservé que si les étudiants reçoivent un appui institutionnel pour leur écriture et si les programmes en écriture allemands sont à la mesure de rencontrer les nouveaux défis.

\section{Mots clés}


centres d'écriture, discours, réformes de Bologne, pédagogie de l'écriture, Hausarbeit

Institutional writing support is slowly emerging as one of the central components of higher education institutions in Germany. ${ }^{1}$ Although a fairly recent development, German universities have increasingly perceived a need to foster students' 'key competencies'. Universities now aim to increase student mobility in cross-European exchange programs, e.g. working with a unified European-wide credit system and incorporating multiple foreign languages into degree programs. And they aim to develop students' transferable skills in key areas of competence, such as gender competence, media competence and - more recently - writing competence. The latter has led to the development and consolidation of writing labs or writing centres in several universities across the country. ${ }^{2}$

The central questions now facing these writing centres are what sort of support to offer, and how to offer it. Many ideas have been adopted from the well-established field of writing pedagogy in North America, with one main exception: there is nothing comparable to 'composition classes'. For this reason, this article discusses 'writing support' or 'writing centres' rather 'writing programs'. We suggest that the specific development of institutional writing support in Germany, and the responses to the question of how to structure this support, involves a tension between two educational discourses. One we dub the 'Humboldt' discourse, referring to the work of Wilhelm von Humboldt and a traditional sense in Germany that higher education is primarily, perhaps solely, for the cultivation of scholars. ${ }^{3}$ The second we term the 'Bologna' discourse, referring to the recent European-wide reform of higher education, popularly known as the Bologna process, which encourages an understanding of higher education in which its goal is not only to cultivate future scholars but also - and primarily - to prepare students for lives outside academia. Writing centres must currently negotiate these two discourses. We argue in this paper that the outcome of the negotiation could lead to the neglect of one specific and central element of traditional German academic writing: the 'Hausarbeit'.

Sections 1 to 3 embed the Hausarbeit in the context of traditional and contemporary educational philosophies and the stages of development in German writing pedagogy. Section 4 examines (productive) tensions in the relationship between the Hausarbeit and the key 'competencies' envisioned by Bologna discourse. In a final, more normative, move, Section 5 suggests how this tension can be made productive for contemporary writing pedagogy both in Germany and in the wider international academic community.

\footnotetext{
${ }_{1}^{1}$ We would like to thank the two anonymous reviewers for their perceptive and helpful comments.

${ }^{2}$ Although no published overviews are currently available, the following page provides links to various centres, labs and projects: http://www.euv-frankfurto.de/de/campus/hilfen/schreibzentrum/links/schreibzentren_in_deutschland/index.html

${ }^{3}$ The cultivation of the autonomous intellectual capabilities associated with the 'scholar' was also, it should be noted, thought to have practical side effects for professional practice in a small range of official capacities, e.g. as teachers, public administrators or other positions in the civil service.
} 


\section{Humboldt discourse}

The neohumanist educational philosophy, associated with the name of Wilhelm von Humboldt in what was then Prussia, was characterized in one sense by an argument against a utilitarian concept of education widespread during the Enlightenment. The utilitarian framework for education had aimed to transmit socially useful knowledge and skills to young people appropriate for their station in life. Carpenters, tailors, farmers, etc., were to be taught simple religion, sufficient mathematics required for their work and various other practical skills. There was, it was thought, no point in teaching them 'higher learning'. 'The farmer should become [through schooling] a good man, and appropriate to his rank, a useful and active man'; the goal of education was to 'make people better and useful for their civic life' (von Zedlitz, 1980[1787], p. 3). School children were seen as docile creatures to be shaped into useful roles. Similarly, universities were seen as sites of knowledge transmission in which knowledge was handed down by lecturers to their docile students who would adopt roles appropriate and useful for their rank.

Neohumanism challenged this. Education was no longer to be seen as a means of preparing young people for their pre-ordained rank in life, but as ways of developing and strengthening the cognitive, moral and aesthetic capabilities of each individual whatever their background - and thus establishing freedom and harmony in society (cf. Baumgart, 2007). Those sharing this latter view of education, with the associated idea that every individual has a desire to learn about the world and a striving for freedom, brought about changes in the organisation of the academy. The dual structure of teaching and research, where teaching (and only teaching) was conducted at universities, and research was conducted at pure research institutions with no teaching commitment, such as the Berlin Academy of Science, was challenged. Research universities were established which united research and teaching - an entirely novel idea in early nineteenth century Germany. These universities, of the type established by Humboldt, became sites of research as well as of teaching, i.e. sites of knowledge production (Kruse, 2006).

One central element of the new universities was their seminar structure, and a central element of the seminars was the Hausarbeit, an extended and complex written seminar paper. This genre is also known as Seminararbeit or Semesterarbeit. We use the term Hausarbeit to describe a paper that is characterized as follows:

- Approx. 6,000 to 12,000 words

- Topic selected freely by the student from any field within the discipline

- Responsibility for finding an appropriate research question lies with individual student

- Independent search for literature and/or independent empirical research

- Methodical approach; students must explicitly articulate their approach to their topic

- Written independently at home, often during vacations

- Style orientated toward published journal articles in the discipline

Overall, this list indicates that the Hausarbeit aims to be - or to simulate - a genuine, published, research paper, drawing on and extending students' ability to research independently and to convincingly present their analysis, reasoning and/or 
conclusions. Hausarbeiten and the seminars in which they were written thus constituted a major curricular shift from lecturing to student participation. Rather than lecturers passing on knowledge and students being tested orally on the accuracy of their learning, students were required to actively discuss issues, interpret texts and participate in the discourse community by writing papers (cf. Kruse, 2006, p. 338). Students generally wrote one paper (Hausarbeit) per seminar (approximately two per semester) that showed they had studied original source literature and engaged with the discursive practices of their discipline. Minimal control or support from professors was offered, but students received feedback from other students and had to present their results in the seminar (Pohl, 2009, p. 50). Although the element of peer feedback has largely disappeared, the central characteristics of Hausarbeiten remained basically unchanged in many fields in German research universities until the turn of this century and the rolling out of the Bologna Process.

\section{The image of students in Humboldt discourse}

That these seminars aimed to cultivate independent future scholars is expressed in seminar regulations issued by the Prussian Ministry of Education from 1812 to 1839 and analyzed by Otto Kruse (2006). The Theological Seminar Berlin (in 1828), for instance, aimed to 'direct the students in their own scholarly work and research' (as cited in Kruse, 2006, p. 342). The Philological Seminar Berlin (in 1812) stipulated that students 'should be educated and trained through as broad a range of exercises as possible and through literary support of every kind to the core of science so that these studies can be maintained, reproduced and extended by them in the future' (as cited in Kruse, 2006, p. 342). These seminars were quite elitist (Pohl, 2009, p. 51). Students had to apply for them with sample research papers. It was expected that the students would play a key role in establishing and developing the new emerging disciplines. As noted above, Hausarbeiten were written to be published and discussed within the discourse community.

The idea behind the seminar and the Hausarbeit was thus basically to cultivate future scholars who were (i) aware of the argumentation strategies of the discipline in which they were studying, and (ii) able to deploy these strategies themselves in independent work. For Kruse (2006), this indicates that early versions of pedagogies of writing-in-the-disciplines and writing-to-learn played a pivotal role in the development of the Humboldtian research university (p. 348).

What these pedagogies lacked in the nineteenth century was a sense of the need for individual or institutional support for students' writing practices. Since higher education was primarily considered to be about developing future scholars, and scholars would arrive at university already knowing how to write academic texts, there was no need - it was thought - to assist them with their writing. This assumption remained firmly in place, even as the university changed from an elitist institution to a larger institution with a broader intake of students from more diverse backgrounds. No longer was the Hausarbeit meant to play a genuine role in the academic community. Its central function changed from participation to assessment, but students still had to (and have to) write as if they would publish and as if they were part of the discourse community. This has led to a paradoxical situation in which on the one hand the signal strengths of the Hausarbeit such as fostering independent research and in-depth 
engagement with theoretical and empirical issues remain, yet at the same time, the Hausarbeit now places additional demands on students. Not only do they have to write to a standard and in a style appropriate to 'real' researchers and academics, they also have to fictionalize themselves as researchers/academics rather than as assessed students (cf. Pohl, 2009, p. 16).

For many faculty members in Germany, socializing future scholars into taking active (leading) roles in the discourse community remains the primary goal of university education, and since this was always done without institutional assistance for student writing, some still see little need for universities to offer writing support. Recent discussions, sparked by the Bologna process, about the state of higher education in Germany and the need for significant reforms are, however, leading to debates sometimes quite heated - about precisely these goals and methods of the traditional university. ${ }^{4}$

\section{Bologna discourse}

In 1999, an inter-ministerial meeting with participants from 29 European countries was held in Bologna, Italy. The declaration signed there became one of the most visible elements of what has been called the Bologna process, Bologna accords or the Bologna discourse (Keeling, 2006). These terms refer to the ongoing process of negotiating objectives for higher education reform which are now impacting on the educational systems of 40 European countries from Russia to Portugal, Norway to Greece. Major stakeholders involved include the national governments of the participating countries, the Council of Europe and the European Commission. Although the policies created are not legally binding, they have set in motion the restructuring of almost all aspects of higher education.

Key aspects of the Bologna process, which are variously debated, criticized, negotiated or adopted in the diversity of local settings across Europe, are student mobility (enhanced, for example, by the European-wide credit transfer system, ECTS), ${ }^{5}$ quality assurance (through, for instance, developing comparable assurance criteria for degree programs across Europe), degree structure (which in recent practice has led many countries to adopt a 3+2+3 system: three years of undergraduate [Bachelor] study followed by two years of postgraduate [Master] study and three years of further research for a doctoral degree), and curriculum development (seen, for instance, in the overall shift in focus from teaching to learning, the pledge to state clear learning outcomes for courses and the increase in independent learning). Together, these elements create a potent mix of educational change affecting educational philosophies, institutional competitiveness, national identities, and practices of subjectification.

In Germany the reforms have created the most impact in the shift from the traditional degree structure which was/is based on the seminar system to a Bachelor-

\footnotetext{
${ }^{4} \mathrm{~A}$ recent heated debate about post-secondary writing instruction on the website of the respected weekly newspaper, Die Zeit, illustrates that this is still an emotional issue, not only for academics but also the wider population (http://www.zeit.de/studium/uni-leben/2010-07/schreibwerkstaetten-unis).

${ }^{5}$ One ECTS point corresponds to an average student workload of 25 to 30 hours. In one year 60 ECTS should be acquired, corresponding to a work load of max. 1800 hours, which corresponds to full time study with approx. six weeks vacation. Depending on the university, a Bachelor degree requires 180-240 ECTS points; a Masters degree 60-120 ECTS points (http://www.hrkbologna.de/bologna/de/home/1923_2116.php).
} 
Masters degree structure. Before the introduction of the Bachelor and Masters structure, students in Germany completed only one lengthier degree (Diplom or Magister) which led directly to doctoral study. The academic quality of final year students was equal to, if not higher than, Masters level work. Students studied at their own pace, with no external deadlines. Although some finished their degree in the 'regulation period' of eight or nine semesters, by far the majority studied for longer, using the freedom inherent in the system to study additional courses without necessarily submitting a Hausarbeit, and/or to become deeply involved in researching for their Hausarbeiten. Anecdotal evidence suggests that where in North America or the UK it is common for Bachelor students to revel in writing an essay 'overnight', in Germany it was common for Diplom or Magister students to discuss the 'months' they had spent on a Hausarbeit. It was not unknown for students to complete their degree in 25 semesters while, for instance, simultaneously working part-time. A serious drawback in this system was that many students dropped out before completion. ${ }^{6}$

\section{The image of students in Bologna discourse}

A central element implicated in recent reforms is the change in practices of subjectification. No longer are all Bachelor students treated as, and expected to become, future scholars. After completing the Bachelor level degree, many leave the university and find employment in non-academic fields. Although this has been true for some years now, research universities did not always acknowledge the future career trajectories of their students, nor think it was the university's responsibility to prepare students for their careers. In the Bologna discourse, employability, transferable skills, and broader social/professional competencies are taking on a more central role in undergraduate university education.

The new priority of transferable skills is itself full of tensions. While it aims to start from students' needs, e.g. the need for inter-cultural communication skills or professional presentation skills, and to help students actually complete their degrees, it cannot avoid being part of the contemporary neo-liberal educational discourse. Education no longer solely aims to produce independent scholars who value knowledge production for the sake of knowledge production, but also to meet the needs of individuals desiring successful future (non-academic) careers.

Thus an orientation to careers and the market becomes more central and students start to be treated as what Peter Miller and Nikolas Rose (1990), Ulrich Bröckling (2007) and others have dubbed 'entrepreneurial selves' and James Paul Gee (2004) 'shape-shifting portfolio people'. In this aspect of the Bologna discourse, it is normal and necessary to act as entrepreneurs in all areas of one's life. At work, at home and at school, in relationships and in sport, a key competency is to be able to develop oneself, to be enthusiastic, flexible and enterprising. From the perspective of writing pedagogy, this discourse is articulated through the desire to assist students in writing, for instance, application letters, resumes and a larger number of short texts for portfolio assessment. Dealing with deadline pressure has also become a major element of

\footnotetext{
${ }^{6}$ Children begin school in Germany when they are 6 or 7 years old. Those who intend to go to university attend school for 13 years (recently, this has been reduced in many regions to 12 years). Men have to either do compulsory military service for nine months or alternative community service for 12 months. Hence few students begin university before the age of 19 or 20 .
} 
students' writing practices. The pressing question is now: where does the 6,000 to 12,000 word Hausarbeit with its extensive independent research component figure in this new climate?

Before turning to this specific question, the next section first outlines the context of institutional writing support in Germany.

\section{The development and consolidation of institutional writing support}

In order to support our argument that the Hausarbeit could help institutionalise writing support in Germany, this section outlines the development and consolidation of writing support in German higher education. As noted above, for many years there was no explicit writing support at German universities. As in many other European countries, learning to write took place implicitly (Bräuer, 2004; Donahue, 2009) or was supposed to have been taught at the Gymnasium, the secondary school for young people intending to go to university. ${ }^{7}$ Although these schools taught students to write short essays, the orientation tended to be towards a fairly simple Introduction-BodyConclusion structure, with no extended work being conducted. ${ }^{8}$ Writing instruction at most schools was also quite product-oriented. Essays are written during in-class exams without a chance for peer feedback or time to draft and revise (Bräuer, 2006). Students thus had to develop their post-secondary education academic writing skills 'on the job', i.e. while preparing their assignments. An independent discipline such as composition studies has not (yet) developed in Germany.

Given this context, it was therefore quite a radical step when in 1993 the first German writing lab was set up at the University of Bielefeld. The funding for the lab was competitively awarded from the North-Rhine Westphalian Ministry of Science, i.e. the lab operated as an independent cell rather than an integral part of the university (Frank et al., 2003). Although this first German writing centre started 60 years after the inauguration of the first writing centres in the USA and 20 years after writing centres became an accepted part of North American university life, there seem to be parallels between the developments in North America and Germany.

To draw out these similarities, we draw here on Christina Murphy and Joe Law (1995) who locate several stages in writing centre development. First writing centre work was problem-based; the centres were seen as 'fix-it-shops' to solve the problems of weak students. After the paradigm shift from product-orientation to processorientation in rhetoric and composition, writing centres saw themselves as institutions

\footnotetext{
${ }^{7}$ In most parts of Germany, students go to three different types of school at the age of 10 after only four years at primary school. Children are given a recommendation for one of three schools: the 'Hauptschule' should prepare students for basic jobs (e.g. factory work) and finishes after ninth or tenth grade. The 'Realschule' should prepare them for more demanding practical jobs (e.g. mechanic, hairdresser) and finishes after tenth grade with an exam. The 'Gymnasium' finishes after grade twelve or thirteen with the 'Abitur' which enables students to study at university. Many studies show that the German school system is one of the most inequitable systems in Europe, because decisions on later careers are made at such an early age. Children from non-academic backgrounds are much less frequently given a recommendation for the Gymnasium. A fourth school type, the 'Gesamtschule' (comprehensive school) tries to combine all three types of secondary education but suffers from ambitious parents pushing their children to the Gymnasium (cf. Becker et al., 2007; Uhlig et al., 2009).

${ }^{8}$ Some federal states recently started to make a larger and more independent research paper a part of the final exams to bridge the gap between school and university a little bit better ('Facharbeit').
} 
which attended more to developing the person of the author than to 'correct' texts. Writing was seen as a tool for learning and personal development. The third turn came with social constructionism: writing centres now saw themselves as places where knowledge of discourse communities was negotiated. In the flattened hierarchy in which students needed to be socialised into their community, peer tutoring took on an increasingly central role (Murphy \& Law, 1995, p. xii).

\section{Problem-based writing support}

These stages can also be identified in the history of writing centres in Germany. The first years of Bielefeld's writing lab focused on students' problems: there was felt to be no institutional awareness of students' writing problems at all, although these problems could easily be observed (Frank et al., 2003). Students often failed to write and submit Hausarbeiten in particular seminars. Often they dropped out of their degree programs because of writing difficulties - but there was no statistical evidence to back up these observations. Andrea Frank's Bielefeld team offered individual counselling sessions to develop a more nuanced understanding of the challenges facing German students in their writing. This helped the team to develop workshops and small teaching units for courses to teach academic writing.

\section{The process approach}

During that period, the writing lab developed a variety of approaches: they began to offer individual consultations and intensive group workshops for students, help for teaching assistants working with professors' classes and support for academic staff (Frank et al., 2003). Frank et al. (2003) stress that working together with faculty and drawing attention to the writing process is one of the most important goals of the writing lab's work: 'We [...] try to explain why the qualifications attained in school are usually not enough to produce academic papers without further support. We pass on the impression we receive through our advisory work that students very often begin to work on their papers rather unsystematically. For instance, due to inadequate knowledge about the writing process, they fail to distinguish between the different stages of the writing process, and thereby overtax themselves' (p. 170).

In 1997, Gabriela Ruhmann, a pioneer in this field, left the Bielefeld writing lab to set up a second writing centre at the University of Bochum, operating along similar lines, e.g. placing great weight on collaborating with faculty, raising awareness of the writing process and highlighting writing as a learning tool. Over the next few years, small writing centres were established in several other German cities, e.g., Chemnitz, Erfurt and Munster. These centres were, however, very dependent on the dedication (overtime) of enthusiastic individuals and often stagnated when these people left.

A major triumph for the consolidation of writing centres as an integral part of higher education was when, in 1998, the writing lab in Bielefeld managed to become a regular part of the university, no longer depending on externally awarded grants (Frank et al., 2003, p. 166). This was not only a financial issue, but an issue of recognition for the importance of the work done by the writing lab. Financing has, nevertheless, remained a difficult issue for institutional writing support. Several writing centres folded after a short period because they lacked funding. To understand this, it perhaps helps to recall that in Germany, university education is (or was) free of charge. Only very 
recently have (relatively low) tuition fees been introduced, and in some states such as Berlin, students still do not pay tuition fees; universities were previously completely financed by the state. This, although good in many ways, makes it very difficult to establish new structures such as writing centres, because they always compete with other disciplines for the fixed amount of money a university gets from the state.

\section{Social constructionism}

The turning point towards a more social constructionist perspective followed in 2001: Set up by Gerd Bräuer, the writing centre at the University of Education (PH) Freiburg also brought 'peer tutoring', as it is known at most US and Canadian writing centres, to Germany. Compared to the slow beginnings of Germany's general writing pedagogy, peer tutoring quickly became very popular. Many of the newer writing centres in Germany work with peer tutors, e.g. Frankfurt/Oder and Göttingen. The writing labs in Bielefeld and Bochum also set up peer tutor-based consulting services in 2008. A first peer tutor conference, organised by Katrin Girgensohn and her tutors in 2008, took place at the European University Viadrina in Frankfurt/Oder 2008 and will be held annually. A peer tutor newsletter is published regularly and other projects are developing..$^{9}$ Central to this approach is the notion of academic writing as the practice of entering a socially rich discourse community; of learning the cultural norms, the routines, the expectations, and how to create space for manoeuvring and negotiating these norms, routines and expectations. Peer tutoring is invaluable for this approach because it provides this social knowledge in a non-hierarchical way, freed from relations of assessment (Bruffee, 1995). ${ }^{10}$

Overall then, current institutional writing support in Germany revolves around writing centre work offering peer tutoring, faculty work and short intensive writing workshops. These shorter workshops fit into today's university structures, since universities are required to offer explicit support for the development of students' 'key competencies'. Often they transfer this responsibility to career centres or writing centres. Since writing workshops explicitly develop specific key competencies, they can count for credit points (ECTS) at an increasing number of universities. All other writing education is still located in the disciplines and often remains implicit.

\section{Structural tensions}

To return to our question above: where does the German Hausarbeit fit into this system? Some say the mantra of key competencies within the Bologna process means the Hausarbeit is simply no longer appropriate or necessary. Students often have an enormous workload, partly because university administrations or the professors redesigning the new Bachelor degree programs have been reluctant to reduce the amount of content (readings, etc.) in the courses, although students are completing their undergraduate degrees in less time than it took to complete the previous Diplom or

\footnotetext{
${ }^{9}$ For further information on peer tutoring, see http://www.euv-frankfurto.de/de/campus/hilfen/schreibzentrum/Peer_Tutoren/index.html. The first peer tutor newsletter (September 2008) is available at: http://www.euv-frankfurt-o.de/de/campus/hilfen/schreibzentrum/ dokumente/Der_Schreibtutoren_Newsletter_September_2008.pdf

${ }^{10} \mathrm{~A}$ fourth stage, conceptualizing the work of writing centres in contexts of globalization as the facilitation of multiliteracies, discussed by Nancy Grimm (2009), is very slowly beginning to emerge but goes beyond the scope of this article.
} 
Magister degrees (Statistisches Bundesamt, 2009). Furthermore, an intrinsic part of Bologna is to have comparable forms of assessment all over Europe, in part to make cross-European exchange easier. The Hausarbeit, as one single extended paper which is the only assessment during a given course, and thus determines the grade at the end of the semester holidays, is difficult to embed in the European-wide system. In many classes, short essays, multiple choice tests or oral exams are beginning to displace the Hausarbeit. Other tasks include, e.g., the requirement to write application letters, book reviews, etc.

Partly due to time pressure, then, and partly due to a certain amount of homogenization across Europe encouraged by educational policy guidelines, 'Bologna discourse' is leading to the replacement of the Hausarbeit by shorter assignments in an increasing number of German university classes. Nevertheless, statistics from the Writing Centre at the European University Viadrina in Frankfurt/Oder show that from 2007 to $2010,40 \%$ of the students who used the Centre requested support for their Hausarbeit.

For many observers, the central failing of the Bologna reforms in Germany is that students are no longer able to develop the independent research skills to make them thinking academics and intellectuals; a common phrase in Germany to refer to the changes is that universities are becoming verschult, i.e. increasingly 'like schools' in which students are spoon-fed knowledge and given short assignments rather than exploring the limits of their intellectual agility. Many fear that the Humboldt discourse of scholarly freedom and excellence (which is of course a radical idealization of Humboldt's writings and of the practices of his time) is being usurped by Bologna. The question now is, thus, whether the German Hausarbeit, and the intellectual demands which that form of independent research places on students from the very start of their degrees, must be relinquished to the Bologna discourse. Can it claim a role in contemporary universities, both in Germany and in the wider international academic community? And why should it?

One oft voiced answer is no, it cannot. Frank (2006) cites a professor at the University of Bielefeld who complains about the large number of poor Hausarbeiten he has received since the Bologna process was set in motion (slide 13). In his opinion this is because 'weaker' students who in the old Diplom or Magister degrees would have participated in his class but not submitted an assignment, are now all submitting papers because they need the ECTS-points for attending his class; they have no time to attend classes without gaining credit, as was often the case in the past: 'We always had weak students in the class, but we very rarely got to see their products'. Frank concludes that the Bologna process makes problems visible that have long existed. A straightforward consequence could be that, since all students must now be supported, such complex writing tasks should be removed from the requirements of the Bachelor (perhaps moved to the Masters, although similar issues seem to exist there).

A more optimistic consequence is that this is precisely the time to sensitize university teachers to the needs of writing pedagogy, and the need to develop systematic institutional writing support. Looking at the Bologna process at German universities so far we fear that the first alternative will happen. Our recommendation perhaps unsurprisingly given our disciplinary affiliations - is that Germany grab this opportunity. Other European countries, such as Norway, have shown ways in which the 
Bologna process can be used as a stimulus to establish and consolidate writing pedagogy at universities (Dysthe, 2007).

\section{Developing generic and specific competencies}

One way to maintain the Hausarbeit is to embed it in the terms of the Bologna discourse, i.e. to describe it as a significant tool for building key skills and generic competencies. This is not to relinquish Humboldtian discourse, but to draw attention to the possibility of combining both Humboldt and Bologna discourse. The tensions between them need not be reduced to a zero-sum game, as many in the public debate on higher education in Germany argue. As shown above, the development of key competencies is a central goal within contemporary higher education. There are many reasons to see the Hausarbeit not only as a genre that cultivates future scholars, but also as facilitating generic transferable skills. The key to this argument is the not-onlybut-also discursive move. Looking back to history we see that Hausarbeiten were presented as tools for learning-to-learn from their very beginning, deep in the Humboldt discourse. Pohl shows that the philosopher Johann Gottlieb Fichte $(1817,2009)$ stressed this when he wrote:

When not only the given is learnt, but at the same time the art of learning itself is learnt and practiced, the capability to learn everything, and to learn easily and confidently, is developed; and there emerge artists of life. (as cited in Pohl, 2009, p. 57 , our translation).

This is also true today. As we suggest in the right column of Table 1, a broad range of key competencies suggested by Bologna can be practiced by writing a Hausarbeit. The left column draws on a recent OECD publication, widely referred to in discussions on the Bologna reforms, which defines three categories of competence, listing three key competencies in each category (Rychen \& Salganik, 2003; see Table 1, left column). These competencies are, according to the OECD, the 'Key Competencies for a Successful Life and Well-Functioning Society', i.e., essential, in their view, for the personal and social development of individuals in a modern, heterogeneous, global world.

A problem with the current discussion of the reforms is that those who disagree (vehemently) with the neoliberal tendencies of educational policies have refused to engage in debate with these reforms. The debate is thus conducted without the opponents. Our suggestion is to adopt the terms used and show how the writing practices associated with the Hausarbeit, a nodal point of Humboldt discourse, can also speak directly to key competencies (as Ruhmann, 2005, pp. 1-3, also does). Our aim is to appropriate the Bologna discourse for Humboldtian ideals, or, one could say, to overidentify with Bologna discourse in order to promote rather than reject the Hausarbeit (cf. Žižek, 2009).

\section{Table 1: Key competencies and Hausarbeit writing practices}




\begin{tabular}{|l|l|}
\hline Key competencies (Bologna) & Hausarbeit writing practices \\
\hline Category 1: Interacting in socially heterogeneous groups
\end{tabular}

${ }^{11}$ Given our understanding of writing as inherently socially embedded, we understand 'writing practices' in the broad sense, i.e., including a range of social, political, cultural and interpersonal practices, or, to be more precise, including interpreting the assignment, negotiating (unrealistic) expectations, resolving conflicts, questioning power hierarchies, etc. (cf. Grimm, 2009). 


\begin{tabular}{|l|l|}
\hline & $\begin{array}{l}\text { a way that allows them to complete it } \\
\text { successfully and on time }\end{array}$ \\
\hline $\begin{array}{l}\text { 2.3 The ability to defend and assert one's } \\
\text { rights, interests, limits, and needs }\end{array}$ & $\begin{array}{l}\text { defend and assert their right for } \\
\text { feedback from professors, and for } \\
\text { consultation from writing centres } \\
\text { clearly state that this } \\
\text { workload/deadline is too much }\end{array}$ \\
\hline Category 3: Using tools interactively/reflexively \\
\hline 3.1 The ability to use language, symbols, \\
and text & $\begin{array}{l}\text { Students have to } \\
\text { clearly express a focused research } \\
\text { question they have designed } \\
\text { themselves } \\
\text { express their own argumentation and } \\
\text { relate it to the broader literature } \\
\text { communicate in the terms of the } \\
\text { specific discourse community or } \\
\text { negotiate a space at a distance to the } \\
\text { discourse community yet not } \\
\text { irrelevant }\end{array}$ \\
\hline $\begin{array}{l}\text { reconstruct the current knowledge on } \\
\text { the topic and summarize relevant } \\
\text { information }\end{array}$ \\
\hline $\begin{array}{l}\text { information } \\
\text { engage with the methods of their } \\
\text { discipline } \\
\text { interactively) } \\
\text { poluate truth claims, develop critical } \\
\text { positions and argue for them } \\
\text { convincingly }\end{array}$ \\
\hline $\begin{array}{l}\text { use computers, databases, research } \\
\text { software } \\
\text { design multimodal Hausarbeiten }\end{array}$ \\
\hline
\end{tabular}

The Hausarbeit is not the only assignment to help develop these skills and competencies; a number of these competencies can be developed through short essays, portfolio work, etc. The practices italicised in Table 1 are, we argue, specific to the Hausarbeit. In brief, these can be summarised as three specificities. First, the Hausarbeit is a good deal longer than any other university assignment. This brings different demands of punctuality and time management which are not relevant to the three-page essay. A Hausarbeit can simply not be started and completed on the night before submission. It also adds complexity to tasks such as engaging with the methods or communication practices of a given discourse community. Sustaining a mode of communication/argumentation over 12,000 words is a different task than sustaining it over 1,000 words. 
Second, students must design their own research question. They do not write the Hausarbeit in response to an assignment created by the faculty member. This necessitates particularly deep engagement with the practices, identities and concerns of the field in question, more so, we believe, than answering one of a selection of pre-set questions.

Third, and intimately related to the first two, is the question of independence. Not only is the research question designed independently and the final lengthy paper written independently, but the research must also be conducted independently. In our broad understanding of 'writing', this research, be it a theoretical literature-based Hausarbeit or an analytical/empirical paper, is also part of the writing process. Reconstructing current knowledge on a given topic thus involves more extensive use of databases, journals and books than seems necessary with shorter essays where a bibliography of five to ten references is not unusual. And it involves a constant cycle of reading, writing and reflection. Again, given the length of the Hausarbeit, it is almost impossible to write it in one go after the research has been completed.

Related to this independence is a further competence, which is (unremarkably perhaps) absent from the OECD publication cited in Table 1, and which we cautiously believe is fostered by the affordances of the Hausarbeit slightly more than is possible in shorter assignments: the long-held goal of fostering critical thinking and a questioning of contemporary social/power relations. The hope here would be that by engaging in such depth with discourse practices and with the expectations and standards of academic writing, student-writers gain experience of the constraints and politics of independence, and reflexive distance from the norms of contemporary knowledge production. This process can, of course, be facilitated by peer tutoring or other forms of writing support (cf. Grimm, 2009).

Aside from these concerns, our central point here is that the Hausarbeit need not be seen as a dusty relict of more elitist periods in German higher education. Given appropriate writing support and clarification of what precisely the Hausarbeit aims to achieve - on the one hand, independent academic excellence and on the other, transferable skills - there is indeed a strong case to be made for retaining and developing this extended research paper as a central component in many university courses in Germany, and perhaps introducing it in other countries.

\section{Developing institutional writing support}

The question should, therefore, not be whether the German Hausarbeit is worth keeping, but how it can be kept under the conditions of the Bologna process. We agree with Ruhmann and other German writing teachers (e.g. Keseling, 2004) that it would be less useful to adopt mandatory general composition classes (p. 309). Writing can continue to be taught in the disciplines to German students. However, it needs to be taught explicitly and supported institutionally by, for instance, policy makers, faculty, peer-tutoring and new modes of scholarly participation.

\section{Educational policies}

We are convinced that the only way to retain and develop the role of the Hausarbeit is to combine bottom-up and top-down processes. A bottom-up-process was and still is the way writing centres like Bielefeld and Bochum operate. They are 
successful, but it took them many years to be accepted by faculty members. We fear that if we take this gradual approach, the Hausarbeit will be extinct before it is saved. Pohl (2009) suggests that the Hausarbeit could only become the main genre at German universities because the state government intervened with top-down legislation (p. 18). Curriculum policy fostered the change of the Hausarbeit from authentic research to assessment. This brought many difficulties and erased some of the intended effects but it also helped to establish a new culture of learning. The current transformations in university culture are also to a certain extent the result of European and national policies. Why not highlight the advantages of the Hausarbeit in explicit curriculum policies recommending this type of learning culture?

\section{Faculty}

At the same time, bottom-up processes are essential. Ruhmann (2005) suggests that faculty divide the process of writing a Hausarbeit into small steps and integrate these steps into seminars, combined with giving and receiving peer feedback. To include peer feedback would recall the roots of the Hausarbeit, where students received feedback from other students during the seminar. It increases the extent of team work and the resulting need to cooperate and manage conflicts - in the writing process. It also helps deal with the growing problem of plagiarism. The extent of plagiarism is one indication of how little support students receive in their writing tasks. Professors are used to seeing only the 'result' of the long writing process and therefore cannot identify whether students wrote their work on their own or simply bought/copied it. Splitting the Hausarbeit into smaller steps and reading, commenting on these initial drafts or sections removes this issue entirely. Furthermore, students' reflections on their writing practices and revisions could be added to the Hausarbeit, creating a portfolio.

Of course, integrating this into seminars means reducing other seminar content and establishing a new learning culture. Writing centres therefore need to support faculty, highlighting the benefits of working in this way within their disciplines. Writing instruction could go hand in hand with a shift towards more autonomous learning - as the shift from teaching to learning in the Bologna process recommends.

\section{Peer-tutoring}

Another means of maintaining the Hausarbeit lies in peer tutoring. In the early days of peer tutoring in Germany it was feared that tutors couldn't work with the genre Hausarbeit due to its length. How can a tutor deal with a 12,000 word paper in a 20minute drop-in-consultation, especially when the paper comes from an unfamiliar discipline? Today we have realised that it is often as valuable to talk about small parts of a Hausarbeit as it is to read the whole text. A lot of consultation time is spent talking about developing research questions, dealing with literature, etc. This means that tutors often listen to ideas and support conceptual work rather than looking at actual texts. For example, in summer $2008,51 \%$ of all consultations engaged with a Hausarbeit at the European University Viadrina's Writing Centre were conversations without texts. One third of these conversations dealt with finding a topic and/or a research question. Of those tutees who brought their texts to the writing centre, $60 \%$ wanted to talk about lower order concerns (Reigstadt \& McAndrew, 1984) such as grammar, spelling or citation guidelines ( $63 \%$ of these tutees were non-native speakers). In these cases it 
generally worked very well to work together on extracts of the Hausarbeit and identify typical errors. Afterwards, tutees were able to look for these errors independently. These experiences show that peer tutoring can be used very effectively to support students writing a lengthy Hausarbeit.

\section{New media, new participation in discourse communities}

A third way to support the writing of Hausarbeiten is to remove (or reduce) the fictional component of writing 'as if' one were a member of the discourse community. New media offer several ways of turning research assignments into genuine contributions to academic communities. First, blogs are increasingly used to discuss course readings; they can also be used to discuss sections of Hausarbeiten. This enables not only peer tutoring at a distance, but also other users, perhaps searching for specific terms or theoretical approaches, to comment on posts, or to use the posts as a way into the subject.

Second, websites enable completed course work to be uploaded, either as it was submitted or after editing and formatting to look like a journal article. Finally, print-ondemand technologies enable students to sell their Hausarbeiten as short books. Where blogs and websites can also be used for shorter assignments such as essays, this final version is indeed only available for Hausarbeiten which are of sufficient length to warrant a book format (e.g. the Grin publishing house publishes Hausarbeiten and other texts at no cost to the author, http://www.grin.com/de). Whichever format institutions adopt to make student texts available as part of a broad international discourse community, the awareness of other readers, beyond the assessing professor, promises to radically alter the writing process.

\section{Conclusion}

In our outline of the development and establishment of institutional writing support in higher education in Germany since the 1990s, we have indicated that today's writing centres are embedded in a tension between the 'Humboldt discourse' of scholarly independence still alive and well in German research universities and the 'Bologna discourse' which places far more emphasis on employability and a range of transferable skill. Where the former is associated with a form of subjectification addressing students as future scholars, the Bologna form of subjectification addresses students as shape-shifting portfolio people.

We have shown that the complex genre of the German Hausarbeit, which has been a fundamental element of Humboldt discourse from its very beginning, is in danger of disappearing entirely. In place of the either-Humboldt-or-Bologna argument, we propose a both-and rhetorical strategy, arguing that the Hausarbeit helps to develop precisely those competencies that the Bologna discourse requests, like interacting (cooperating, managing conflict) in socially heterogeneous groups, acting autonomously and using the tools of semiotics, language, knowledge and technology in an interactive and reflexive way.

We strongly believe that the Bologna process is an opportunity to foster a development that began in Germany 15 years ago: the establishment of writing centres offering peer tutoring, writing workshops and faculty work. Writing centres could bring the Hausarbeit back (forward) to its roots by enabling peer feedback to contribute to the 
text-in-progress. They could also develop what Germany with its lack of composition classes never had: awareness of writing as a social process, the need to distinguish the writing process in small and manageable steps, and also the difference it makes for students to write for a genuine (virtual) audience beyond the assessor.

Nevertheless, given the current structural situation in most German universities (lack of funds, overworked students and faculty) the further consolidation of writing centres - and with that the development of the German Hausarbeit - may need to take a step beyond the bottom-up process with which it started. Policy-makers and/or administrators need to step in, as they have done with various Bologna proposals, and support the institutionalisation of writing support. Only with additional funding will smaller seminar groups, excellence in teaching and support for writing be possible. This argument can be made in Humboldt's terms of cognitive and moral agility and freedom and harmony in society, or in Bologna's terms of employability, key competencies and a successful and prosperous Europe.

\section{References}

Baumgart, F. (Ed.). (2007). Erziehungs- und Bildungstheorien (3rd ed.). Bad Heilbrunn: Klinkhardt.

Becker, R., \& Lauterbach, W. (2007). Bildung als Privileg- Erklärungen und Befunde zu den Ursachen der Bildungsungleichheit. Wiesbaden: VS, Verl. für Sozialwissenschaften.

Bräuer, G. (2002). Drawing connections across education: The Freiburg Writing Centre Model. Learning Across the Disciplines, 5(3), 61-80.

Bräuer, G. (2004). The role of writing in higher education in Germany. In S. Bruce, B. A. Rafoth (Eds.), ESL writers - A guide for writing centre tutors (pp. 186194). Portsmouth, NH: Boynton/Cook Heinemann.

Bräuer, G. (2006). Unsere Schulen gemeinsam bewegen. Ein Plädoyer für eine veränderte Problemsicht (pp. 39-48). In O. Kruse, K. Berger, M. Ulmi (Eds.), Prozessorientierte Schreibdidaktik. Bern: Haupt.

Bröckling, U. (2007). Das unternehmerische Selbst: Soziologie einer Subjektivierungsform. Frankfurt a.M.: Suhrkamp.

Bruffee, K.A. (1995): Peer tutoring and the "Conversation of Mankind". In C. Murphy, J. Law (Eds.), Landmark Essays on Writing Centres (pp. 87- 107), Davis: Hermagoras Press.

Donahue, C. (2009). "Internationalization" and composition studies: Reorienting the discourse. College Composition and Communication, 61(2), 212-243.

Dysthe, O. (2007). How a reform affects writing in higher education. Studies in Higher 
Education, 32(2), 237-252.

Frank, A., Haacke, S., \& Tente, C. (2003). Contacts- conflicts- cooperation. In L. Björk, G. Bräuer, L. Rienecker \& P. S. Jörgensen (Eds.), Teaching academic writing in European higher education (pp. 165-174). Dodrecht, Boston, London: Kluwer Academic Publishers.

Frank, A. (2006, 9 June). Schreiben im Studium und Bologna-Reform. Erfahrungen des Schreiblabors Bielefeld. Paper presented at the 'Forum Schreiben' conference in Winterthur, Switzerland.

Fichte, J.G. (1956) [1817]. Deduzierter Plan einer zu Berlin zu errichtenden höheren Lehranstalt, die in einer gehörigen Verbindung mit der Akademie der Wissenschaften stehe. In E. Anrich (Ed.), Die Idee der deutschen Universität. Die fünf Grundschriften aus der Zeit ihrer Neugründung durch klassischen Realismus und romantischen Realismus (pp. 125-217). Darmstadt: Wissenschaftliche Buchgesellschaft.

Gee, J. P. (2004). Situated language and learning: A critique of traditional schooling. London: Routledge.

Grimm, N. M. (2009). New conceptual frameworks for writing centre work. The Writing Centre Journal, 2009, 11-27.

Harris, M, (1995). What's up and what's in: Trends and traditions in writing centres. In C. Murphy \& J. Law (eds.), Landmark essays on writing centres. Davis: Hermagoras Press.

Keeling, R. (2006). The Bologna Process and the Lisbon Research Agenda: The European Commission's expanding role in higher education discourse. European Journal of Education, 41(2), 203-223.

Keseling, G. (2004). Die Einsamkeit des Schreibers. Wie Schreibblockaden entstehen und erfolgreich bearbeitet werden können. Wiesbaden: VS Verlag für Sozialwissenschaften.

Kruse, O. (2006). The origins of writing in the disciplines: Traditions of seminar writing and the Humboldtian Ideal of the research university. Written Communication, 23(3), 331-352.

Miller, P., \& Rose, N. (1990). Governing economic life. Economy and Society, 19, 131.

Pohl, T. (2009). Die studentische Hausarbeit. Rekonstruktion ihrer ideen- und institutionsgeschichtlichen Entstehung. Heidelberg: Synchron Wissenschaftsverlag der Autoren. 
Reigstad, T. \& McAndrew, D. (1984). Training tutors for writing centre conferences. Urbana, IL: NCTE.

Ruhmann, G. (2005): Über einen ungehobenen Schatz der Hochschullehre. In U. Webers \& O. Gaus (Eds.), The shift from teaching to learning. Konstruktionsbedingungen eines Ideals (pp. 269-275). Bielefeld: CW Bertelmann.

Rychen, D. S., \& Salganik, L. H. (Eds.). (2003). Key competencies for a successful life and well-functioning society. Göttingen: Hogrefe \& Huber.

Statistisches Bundesamt (2009): Bildung und Kultur. Nichtmonetäre hochschulstatistische Kennzahlen Fachserie 11 Reihe 4.3.1, Artikelnummer: 2110431087004. Available online: https://www-ec.destatis.de/csp/shop/ $\mathrm{sfg} / \mathrm{bpm}$.html.cms.cBroker.cls?cmspath=struktur,vollanzeige.csp\&ID=1025071 (13.2.2010)

Uhlig, J., Solga, H., \& Schupp, J. (2009). Ungleiche Bildungschancen: Welche Rolle spielen Underachievement und Persönlichkeitsstruktur dabei? Discussion Paper SP I 2009-503. Wissenschaftszentrum Berlin für Sozialforschung.

von Zedlitz, K. A. (1980). Vorschläge zur Verbesserung der preußischen Schulen (1787). In C. Berg (Ed.), Staat und Schule oder Staatsschule? Stellungnahmen von Pädagogen und Schulpolitikern zu einem unerledigten Problem (1787-1889) (pp. 3-9). Königsstein: Taunus.

\footnotetext{
Bios

Dr. Felicitas Macgilchrist is Research Fellow in the Globalization research unit at the Georg Eckert Institute for International Textbook Research. She is Principal Investigator of Educational Media: Production, Practice, Politics, an ethnographic discourse analytical study of the interaction between educational policies, curriculum work and educational media. Further research interests include academic literacies, discourse theory, curriculum theory, globalization and diversity.

Dr. Katrin Girgensohn is founder and Director of the Writing Centre at the European University Viadrina. She was board member of the European Association for Teaching Academic Writing (EATAW) from 2003 to 2005 and is currently chair of the European Writing Centre Association (EWCA). In 2009 she was a leader at the IWCA summer institute in Philadelphia. Recent publications include Neue Wege zur Schlüsselqualifikation Schreiben (Novel Approaches to the Key Qualification Writing) on autonomous writing groups at universities and Kompetent zum Doktortitel (Attaining PhDs Competently) on writing centre work with doctoral candidates.
} 